\title{
TAFSIR AYAT-AYAT PLURALISME AGAMA PERSPEKTIF HUSEIN MUHAMMAD
}

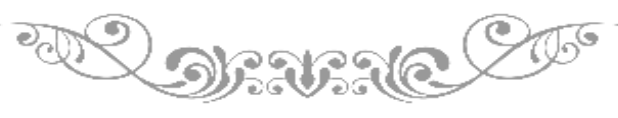

Siti Hajar

IAIN Syekh Nurjati Cirebon

Email: sitihajar.1703@gmail.com

\section{Umayah}

IAIN Syekh Nurjati Cirebon

Email: umayah@syekhnurjati.ac.id

\begin{abstract}
This paper aims to show Husein Muhammad's interpretation on verses related to religious pluralism. To achieve that purpose, the author uses the hermeneutic method of liberation by Farid Esack which wants to show the relationship between the text of the Qur'an and the context of the relationship between religious believers, which will then build justice based on human values. The key to Farid Esack's hermeneutics relates to piety, monotheism, relationships between humans, the oppressed, justice and concrete practices as a form of struggle (jihad) to humanize humans. The conclusion of this paper shows that Husein Muhammad has a very tolerant, wise and full of wisdom in conveying the meaning of religious pluralism verses. He believes that the messages in the Qur'an act as a guide to uphold human values. So that, the verse of religious pluralism requires for an equal position of religious people as God's creatures. There is no justification for certain religious communities which is the most right or which is clearly wrong.
\end{abstract}

Keywords: Pluralisme agama, Husein Muhammad.

\begin{abstract}
Abstrak
Tulisan ini bertujuan untuk memperlihatkan penafsiran Husein Muhammad atas ayat-ayat yang terkait dengan tema pluralisme agama. Untuk mencapai tujuan tersebut, penulis menggunakan metode hermeneutika pembebasan Farid Esack yang ingin memperlihatkan relasi antara teks Alquran dengan konteks hubungan antarumat beragama, yang kemudian akan membangun keadilan berdasarkan nilai-nilai kemanusiaan. Kunci hermeneutika Farid Esack berkaitan dengan takwa, tauhid,
\end{abstract}


hubungan antarsesama manusia, golongan yang tertindas, keadilan serta praktik konkret sebagai bentuk perjuangan (jihad) memanusiakan manusia. Kesimpulan dari tulisan ini menunjukkan bahwa Husein Muhammad memiliki pandangan yang amat toleran, bijak dan penuh hikmah dalam menyampaikan makna atas ayat-ayat pluralisme agama. Ia meyakini bahwa pesan-pesan dalam Alquran berperan sebagai pembawa petunjuk untuk menjunjung tinggi nilai-nilai kemanusiaan. Sehingga, ayat pluralisme agama menghendaki adanya kesamaan kedudukan umat beragama sebagai makhluk Tuhan. Tidak ada justifikasi atas umat agama tertentu yang paling benar atau yang jelas salah.

Kata Kunci: Pluralisme agama, Husein Muhammad.

\section{PENDAHULUAN}

Pluralisme merupakan kata yang sudah tidak asing didengar. Bahkan semakin hari, pluralisme semakin banyak diangkat oleh kalangan akademisi. Kajian ini seringkali dikaitkan dengan multikulturalisme. Pluralisme membahas mengenai pemaknaan atas penerimaan terhadap agama-agama yang berbeda, sedangkan multikulturalisme membahas mengenai kesetaraan budaya.

Islam pada hakikatnya mendalami betul akan nilai-nilai toleransi dan realitas keberagaman yang ada. Hal ini dikarenakan Allah hendak memberitakan hikmah dan pengajaran kepada umat manusia akan adanya keberagaman tersebut. Beberapa hikmah di antaranya ialah agar manusia dapat hidup berdampingan secara damai (QS. al-Kāfirūn [109]: 1-6), saling mengenal (QS. al-Hujurāt [49]: 13), menjunjung keadilan terhadap siapapun termasuk umat non Muslim (QS. al-Mumtahanah [60]: 8-9, [5]: 8), saling melindungi rumah ibadah satu sama lain (QS. al-Hajj [22]: 40), memenuhi hak untuk sama-sama diperlakukan dengan baik (QS. al-Hujurāat [49]: 11-12, al-An'ām [6]: 108) dan menebarkan nilai-nilai Islam rahmatan li al-'ălamìn (QS. [21]: 107). ${ }^{1}$ Dalam hal ini, tentu tidak ada paksaan untuk memeluk dan meyakini suatu agama (QS. al-Baqarah [2]: 256). Karena masing-masing memiliki kedudukannya dalam hal beragama (QS. Âli 'Imrān [3]: 199) dan penting untuk dihormati dalam rangka kemanusiaan (QS. Āli 'Imrān [3]: 84, al-Nisā' [4]: 86). ${ }^{2}$ Ketika memaksakan kehendak, maka ibadah akan berjalan tidak maksimal.

Tentu dalam perjalanannya, penafsiran atas ayat Alquran terkait dengan isu pluralisme agama tidak selalu berada dalam titik yang mutlak. Ia

${ }^{1}$ Umi Sumbulah \& Nurjanah, Pluralisme Agama, Makna dan Lokalitas Pola Kerukunan Antarumat Beragama (Malang: UIN-Maliki Press, 2013), 10-12.

${ }^{2}$ Umi Sumbulah \& Nurjanah, Pluralisme Agama, Makna dan Lokalitas Pola Kerukunan Antarumat Beragama, 50. 
akan selalu memiliki pemaknaan yang beragam sesuai dengan latar belakang penafsir. Dalam hal ini, Husein Muhammad sebagai ulama dan cendekiawan Muslim memiliki ketertarikan tersendiri dengan isu pluralisme agama. Meskipun Husein Muhammad lebih konsen terhadap isu perempuan dan gender yang membuatnya mendapatkan gelar Doktor Honoris Causa (Dr. Hc.) dari UIN Walisongo Semarang di bidang tafsir gender, ${ }^{3}$ namun ia tetap memiliki konsen di isu pluralisme agama. Dengan latar belakangnya yang selalu bersinggungan dengan realitas kemajemukan yang ada di Cirebon dan hal-hal lain yang sudah disebutkan, penulis merasa pemikiran-pemikirannya terkait pluralisme agama penting untuk dikaji lebih mendalam sebagai semangat untuk menebarkan rahmat dan pesan perdamaian kepada alam semesta khususnya bagi masyarakat Indonesia.

Tulisan ini menggunakan penelitian kualitatif dengan metode penelitian kepustakaan (library research). Dalam tulisan ini, sumber data yang digunakan berasal dari buku karya Husein Muhammad berjudul "Mengaji Pluralisme kepada Mahaguru Pencerahan" yang diperkuat dengan wawancara langsung dengan Husein Muhammad. Sumber penunjang yang terkait dengan pokok pembahasan penulis ambil dari dari buku-buku, artikel ilmiah, dan postingan sosial media yang ditulis oleh Husein Muhammad; juga ditambahkan sumber-sumber bacaan lain yang terkait dengan pembahasan pluralisme agama.

Data-data yang diperoleh dianalisis menggunakan hermeneutika Farid Esack yang didasarkan atas kemungkinan seseorang untuk menafsirkan ayat Alquran sesuai dengan pengalaman dirinya dan sosial untuk membaca teks. ${ }^{4}$ Selain itu, seorang mufassir yang sedang membaca teks Alquran akan memaknainya dengan melihat konteks tertentu sesuai keinginannya karena pemaknaan teks masa awal dengan masa sekarang berbeda akibat kondisi sosial kemasyarakatan yang sedang dihadapi berbeda pula. Sehingga dalam perjalannya, seorang mufassir akan terus berusaha menemukan pemaknaan atas ayat Alquran yang sesuai dalam konteks sekarang. ${ }^{5}$

\section{PEMBAHASAN}

\section{Sekilas Tentang Husein Muhammad}

Husein Muhammad lahir di Arjawinangun Cirebon pada hari Sabtu, 9 Mei 1953. Ayahnya bernama Muhammad Asyrofuddin dan ibunya bernama

3 Dede Wahyudi, "Pengakuan Akademik atas Pemikiran Kiai Husein Muhammad," NUOnline, 27 Maret 2019, http://nu.or.id/post/read/104121/doktorhonoris-causabuah-atas-pemikiran-kiai-husein.

${ }^{4}$ Farid Esack, Al-Quran, Liberalisme, Pluralisme Membebaskan yang Tertindas, terj. Watung A. Budiman (Bandung: Mizan, 2000), 36.

${ }^{5}$ Muhtarom, "Mempertimbangkan Hermeneutika Farid Esack untuk Membangun Kerukunan Hidup Umat Beragama," at-Taqaddum Vol. 7 No. 2 (November 2015):198. 
Ummu Salma Syathori. Husein Muhammad berasal dari keluarga di lingkungan Pesantren Dar al-Tauhid, di mana ibunya merupakan putri dari pendiri salah satu pondok pesantren tertua di Arjawinangun yaitu KH. Syathori. ${ }^{6}$ Husein Muhammad kemudian menikah dengan Lilik Nihayah Fuadi dan dikaruniai lima orang anak. Sejak usia dini hingga jenjang Sekolah Dasar dan Diniyah, Husein Muhammad belajar di lingkungan pondok pesantren Dar al-Tauhid bersama kakek dan Asātidh lainnya. Kemudian ia melanjutkan sekolah di SMPN 1 Arjawinangun sambil mengikuti organisasi ekstra di sekolahnya sampai tahun 1969. Setelah menamatkan Sekolah Dasar dan Sekolah Diniyah pada tahun 1966 di lingkungan pondok pesantren Dar al-Tauhid Arjawinangun, kemudian melanjutkan ke SMPN 1 Arjawinangun dan selesai pada tahun 1969. Selesai SMP, Husein Muhammad melanjutkan pendidikannya ke Pondok Pesantren Lirboyo Kediri selama tiga tahun dan setelahnya memilih melanjutkan ke Perguruan Tinggi Ilmu Alquran Jakarta (PTIQ). Setelah lulus dari PTIQ tahun 1979, Husein Muhammad melanjutkan pendidikan ke Universitas alAzhar sesuai arahan dari gurunya di PTIQ untuk lebih memperdalam keilmuan di bidang tafsir Alquran. ${ }^{7}$ Husein Muhammad selesai belajar di AlAzhar tahun 1983 dan kembali ke Indonesia untuk mengembangkan pesantren Dar al-Tauhid yang didirikan oleh kakeknya tersebut.

Husein Muhammad menapaki dunia seputar pluralisme agama dilatarbelakangi konsentrasi beliau terhadap isu-isu perempuan dan kesetaraan gender yang sama-sama bertujuan menjunjung nilai-nilai kemanusiaan. Ia mengembangkan pemikiran dan gagasannya melalui lembaga Fahmina Institute. ${ }^{8}$ Selain itu, Husein Muhammad pernah menjadi Ketua Departemen Kajian Filsafat dan Pemikiran ICMI Kabupaten Cirebon (1994-1999), Pendiri Forum Sabtuan (2000-sekarang), anggota National Broad of International Center for Islam and Pluralisme Jakarta (2003) serta pendiri Institut Studi Islam Fahmina (ISIF) (2008-sekarang). ${ }^{9}$

Selain berorganisasi, Husein Muhammad banyak mengisi acara seminar, dialog dan konferensi baik dalam ranah lokal maupun internasional. Dalam dunia pluralisme, Husein Muhammad mengisi acara di antaranya Fellowship di Institut Studi Islam Modern (ISIM) Universitas Leiden Belanda (2002), Lecture International Scholar Visiting Malaysia (2004), Narasumber seminar internasional "Trends in Family LaW Reform in Muslim Countries" Malaysia (2006), Menyampaikan tulisan berjudul "Alquran and Ta'wil for Equality and Justice" pada acara Global Movement

6 M. Nuruzzaman, Kiai Husein Membela Perempuan (Yogyakarta: Pustaka PesanStren, 2005), 110.

7 Susanti, "Husein Muhammad Antara Feminis Islam dan Feminis Liberal," Teosofi: Jurnal Tasawuf dan Pemikiran Islam Vol. 4 No.1 (Juni 2014): 200-201.

${ }^{8}$ Wawancara dengan Husein Muhammad di kediamannya pada Kamis, 11 Juni 2020.

${ }^{9}$ Susanti, "Feminisme dalam Perspektif Husein Muhammad," 18-20. 
for Equality and Justice in the Muslim Family Malaysia (2009), Speaker dalam workshop Kebebasan Beragama dan Berkeyakinan di Istanbul Turki (2013). ${ }^{10}$

Husein Muhammad termasuk orang yang produktif menulis. Karyakarya Husein Muhammad baik yang ditulis sendiri atau berkolaborasi dengan penulis lainnya yang berkaitan dengan isu pluralisme agama di antaranya adalah: Spiritualitas Kemanusiaan Perspektif Islam Pesantren (Yogyakarta: Pustaka Rihlah, 2006); Mengaji Pluralisme kepada Mahaguru Pencerahan (Bandung: Mizan, 2011); Sang Zahid Mengarungi Sufisme Gus Dur (Yogyakarta: LKiS, 2012); Menyusuri Jalan Cahaya (Yogyakarta: Bunyan, 2013); "Kebebasan Beragama dan Kekerasan atas Nama Agama", dalam Marzuki Wahid (ed), Menggagas Fiqh Ikhtilaf Potret dan Prakarsa Cirebon (Cirebon: Fahmina Institute, 2017); Islam Tradisional yang Terus Bergerak (Yogyakarta: IRCiSoD, 2019); Islam yang Mencerahkan dan Mencerdaskan (Yogyakarta: IRCiSoD, 2020); Dialog dengan Kiai Ali Yafie: Hak Asasi Manusia, Negara Bangsa, Peran Akal, Konservatisme Peradaban Teks, Tafsir dan Upaya Mendialogkan Teks dan Realitas (Yogyakarta: IRCiSoD, 2020) dan Kaidah Cinta dan Kearifan (Cirebon: Fahmina Institute). ${ }^{11}$

\section{Tafsir Ayat-Ayat Pluralisme Agama Perspektif Husein Muhammad}

Pluralisme diyakini Husein Muhammad sebagai sebuah keniscayaan yang Tuhan berikan untuk bisa dipahami dan diamalkan oleh umat manusia. Bentuk pengamalannya ialah bagaimana manusia bisa saling menghargai dan menerima keberadaan orang lain yang berbeda agama dan keyakinannya. Husein Muhammad menuliskan, agama terdiri dari dua komponen yaitu akidah dan shari'ah. Akidah, menyangkut keyakinan kepada Tuhan, sedangkan shari' ah terkait dengan metode, jalan aturan dan cara untuk menuju keyakinannya kepada Tuhan. ${ }^{12}$ Keberagaman shari' $a h$ agama yang ada di dunia merupakan kehendak Tuhan, yang berfungsi untuk menguji pengabdian manusia kepada-Nya. ${ }^{13}$ Pluralisme menurutnya tidak bisa hanya diartikan sebagai suatu pluralitas semata. Pluralitas hanya diartikan sebagai suatu realitas yang ada dalam kehidupan masyarakat, namun pluralisme lebih dari itu. Pluralisme ialah bagaimana suatu paham akan adanya

${ }^{10}$ Susanti, "Feminisme dalam Perspektif Husein Muhammad," 20-21.

${ }^{11}$ Dapat dilihat dalam postingan Instagram Husein Muhammad tanggal 11 Juli $2020 \mathrm{di}$ http://instagram.com/p/CCeDy5OpZuE/.

12 Husein Muhammad, Mengaji Pluralisme kepada Mahaguru Pencerahan (Bandung: Mizan, 2011), 11.

${ }^{13}$ Husein Muhammad, Mengaji Pluralisme kepada Mahaguru Pencerahan, 13. 
pluralitas terutama dalam aspek agama mendapat justifikasi secara teologis atau tidak. ${ }^{14}$

\section{Prinsip Keberagaman Dalam Islam}

Penciptaan manusia dengan berbagai macam identitas dan latar belakang sebagai suatu keniscayaan mengharuskan manusia itu sendiri untuk memetik hikmah dan pengajaran. Dalam Alquran dijelaskan:

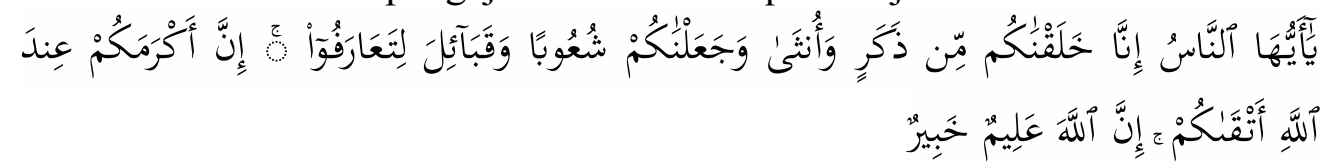

"Wahai manusia! Sungguh, Kami telah menciptakan kamu dari seorang laki-laki dan seorang perempuan, kemudian Kami jadikan kamu berbangsa-bangsa dan bersuku-suku agar kamu saling mengenal. Sesungguhnya yang paling mulia di antara kamu di sisi Allah ialah orang yang paling bertakwa. Sungguh, Allah Maha Mengetahui, Mahateliti." (QS. Al-Hujurāt [49]: 13)

Husein Muhammad menyatakan bahwa li ta'ärafü tidak hanya diartikan sebatas mengenal nama, alamat, identitas diri dan ciri fisik seseorang. Ia dimaknai secara meluas dengan mengenal tradisi, adat istiadat, kebiasaan, gagasan-gagasan dan pandangan yang beragam. Saling mengenal dalam hal ini memberikan kesan untuk selalu menjadi pribadi yang bijaksana, rendah hati dan mengedepankan nilai-nilai kemanusiaan apapun identitasnya. ${ }^{15}$ Kemudian pada kalimat selanjutnya, "Sesungguhnya yang paling mulia di antara kamu di sisi Allah ialah orang yang paling bertakwa". Ayat ini dikuatkan dengan Hadis Rasululah Saw.,

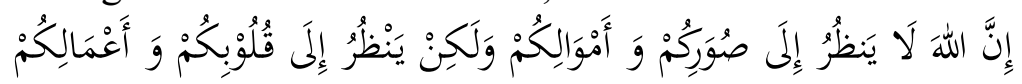

"Allah tidak melihat kalian dari tubuh dan wajah kalian, melainkan pada hati dan perbuatan kalian." (HR. Muslim)

Segala keunggulan, kemuliaan, kesalehan seseorang bukan atas dasar simbol-simbol seperti agama, ras dan semacamnya; melainkan karena ketakwaan kepada Tuhan. Ketakwaan tersebut tidak hanya sebatas dalam bentuk peribadatan kepada Tuhan saja. Takwa juga mencakup kerja-kerja kebaikan untuk menjunjung tinggi nilai-nilai kemanusiaan yang tidak terbatas. ${ }^{16}$

${ }^{14}$ Disampaikan dalam Dialog Bersama Merawat Pluralitas bersama Buya Syakur Yasin, MA. dan Ulil Abshar Abdala di Pondok Pesantren Cadangpinggan Indramayu; Minggu, 06 Oktober 2019.

${ }^{15}$ Husein Muhammad, Samudra Kezuhudan Gus Dur, 107.

${ }^{16}$ Husein Muhammad, Mengaji Pluralisme kepada Mahaguru Pencerahan, 14-15. 
Konsep ketauhidan dalam Islam akan melahirkan konsep kesetaraan dan keadilan manusia yang tidak memandang perbedaan kelompok atau golongan yang berlaku sepanjang masa. ${ }^{17}$ Allah berfirman:



"Dan Kami telah menurunkan Kitab (Al-Qur'an) kepadamu (Muhammad) dengan membawa kebenaran, yang membenarkan kitab-kitab yang diturunkan sebelumnya dan menjaganya, maka putuskanlah perkara mereka menurut apa yang diturunkan Allah dan janganlah engkau mengikuti keinginan mereka dengan meninggalkan kebenaran yang telah datang kepadamu. Untuk setiap umat di antara kamu, Kami berikan aturan dan jalan yang terang. Kalau Allah menghendaki, niscaya kamu dijadikan-Nya satu umat (saja), tetapi Allah hendak menguji kamu terhadap karunia yang telah diberikanNya kepadamu, maka berlomba-lombalah berbuat kebajikan. Hanya kepada Allah kamu semua kembali, lalu diberitahukan-Nya kepadamu terhadap apa yang dahulu kamu perselisihkan." (QS. AlMā'idah [5]: 48)

Peranan Alquran di dunia ini adalah sebagai penyempurna kitab terdahulu, dan ajaran Islam yang dibawa oleh Nabi Muhammad merupakan ajaran penyempurna ajaran-ajaran yang dibawa oleh utusan Tuhan sebelumnya. Ajaran keagamaan dari utusan Tuhan yang berbeda-beda merupakan bentuk optimalisasi penggunaan akal dalam upaya beradaptasi dengan kondisi keragaman dalam mengutarakan ekspresi keyakinannya kepada Tuhan. Husein Muhammad menyatakan bahwa secara literal, Allah menjadikan setiap jalan yang berbeda sebagai suatu keniscayaan dan menghendaki manusia untuk merenungi serta mengambil hikmah atas hal tersebut.

Husein Muhammad menyakini bahwa pluralisme sejatinya mengandung makna ketauhidan di mana masing-masing agama memiliki syariat/jalan yang beragam untuk menuju Tuhan. ${ }^{18}$ Syariat memiliki beberapa bagian. Syariat dalam hal akidah, disampaikan secara jelas dalam

${ }^{17}$ Nurcholis Madjid, "Percakapan dengan Husein Muhammad," (22 Mei 2007), 6. http://nurcholismadjid.org/assets/pdf/pengaruh/Percakapan-dengan-HuseinMuhammad.pdf.

${ }^{18}$ Husein Muhammad, Islam Tradisional yang Terus Bergerak, 261-262. 
Alquran seperti mengenai kedudukan Tuhan Yang Maha Esa, adanya dunia yang abadi kelak pada hari kebangkitan yaitu di akhirat, adanya unsur metafisik yang harus diyakini keberadaannya. Syariat dalam hal ibadah (habl minallah) merupakan interaksi langsung antara manusia dan Tuhan, tidak ada seorangpun yang berhak mengusiknya. Sedangkan syariat dalam hal muamalah tidak diatur secara rinci. Prinsip dasar dalam bermuamalah terhadap sesama manusia yaitu dengan tidak saling menyakiti/berbuat zalim ('Adam al-Zulm), tidak merugikan satu sama lain ('Adam al-Zulm), tidak berjudi ('Adam al-Maysir), tidak memeras atau melakukan riba atas yang lain ('Adam al-Ribā'), saling menerima (al-Ta'radi) dan saling bermusyawarah (al-Shürā). ${ }^{19}$ Oleh karenanya, interaksi antarumat manusia dapat dipraktikkan dan dilaksanakan dalam bentuk apapun.

\section{Persaudaraan Antarumat Beragama}

Allah menghendaki adanya keberagaman agama, dan setiap umat yang menganut agamanya juga beragam tingkat keimanannya. Mereka memiliki kitab suci yang diturunkan dari Tuhan dengan prinsip yang sama yaitu prinsip ketauhidan untuk menegakkan keadilan di muka bumi. Allah berfirman:

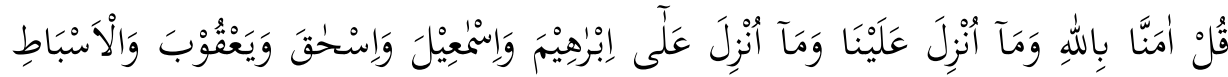

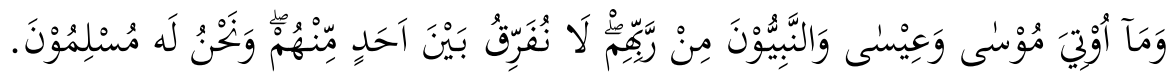

"Katakanlah (Muhammad), "Kami beriman kepada Allah dan kepada apa yang diturunkan kepada kami dan yang diturunkan kepada Ibrāhìim, Ismā'ìl, Ishạk, Ya'qūb, dan anak cucunya, dan apa yang diberikan kepada Mūsā, '̄isā dan para nabi dari Tuhan mereka. Kami tidak membeda-bedakan seorangpun di antara mereka dan hanya kepada-Nya kami berserah diri." (QS. Ali 'Imrān [3]: 84)

Husein Muhammad menyebut bahwa setiap makhluk di muka bumi senantiasa mencari eksistensi Tuhan melalui cara dan bentuk yang berbedabeda. ${ }^{20}$ Oleh karena itu, ajaran dan kenabian para utusan Tuhan patut kita junjung tinggi dan penuh penghormatan karena semua itu sama-sama memiliki satu tujuan yaitu berserah diri kepada Tuhan. Itulah Islam, yang oleh Husein Muhammad diperjelas dengan munculnya ketauhidan; di mana tertanamnya keyakinan bahwa Tuhanlah satu-satunya Zat yang harus disembah dan diagungkan. Dan itu dijumpai pada seluruh agama yang dibawa oleh utusan Tuhan, baik yang dituliskan dalam Alquran maupun yang tidak tertulis. ${ }^{21}$

\footnotetext{
${ }^{19}$ Husein Muhammad, Menyusuri Jalan Cahaya, 19-20.

${ }^{20}$ Husein Muhammad, Samudra Kezuhudan Gus Dur, 118-119.

${ }^{21}$ Husein Muhammad, Mengaji Pluralisme kepada Mahaguru Pencerahan, 5-6.
} 
Dalam Alquran telah jelas disebutkan bahwa Islam adalah agama pembawa rahmat,

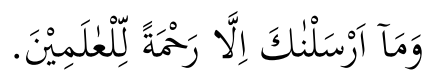

"Dan Kami tidak mengutus engkau (Muhammad) melainkan untuk (menjadi) rahmat bagi seluruh alam.” (QS. Al-Anbiyā'[21]: 107)

Rahmat Tuhan melalui Muhammad dan Alquran berlaku secara global dari masa ke masa. Rahmat merupakan intisari dari sifat-sifat ketuhanan berupa Raḥman dan Rahim, yang artinya memberikan misi untuk menebarkan kasih sayang kepada siapapun di muka bumi. ${ }^{22}$ Husein Muhammad juga sepakat bahwasanya konsep ajaran yang Nabi Muhammad bawa ialah konsep yang memberikan rasa bahagia bagi seluruh umat di seluruh dunia. Pokok-pokok ajaran yang disampaikan melalui Alquran merupakan pokok ajaran yang tidak berubah-ubah, namun dapat diterapkan sepanjang zaman sebagai bentuk kedewasaan akal dalam melihat realitas.

Terkait dengan ayat-ayat mengenai larangan mengatakan hal-hal yang menyakiti orang lain, Husein Muhammad menyayangkan adanya justifikasi 'kafir' terhadap umat agama lain. Umat agama lain lebih layak disebut sebagai non Muslim. Kafir tidak bisa digeneralisasi dan disematkan begitu saja kepada komunitas atau agama yang berbeda dengan kita. Bahkan Alquran menyatakan bahwa penganut agama lain ada pula yang beriman. Alquran secara gamblang menyatakan hal tersebut,

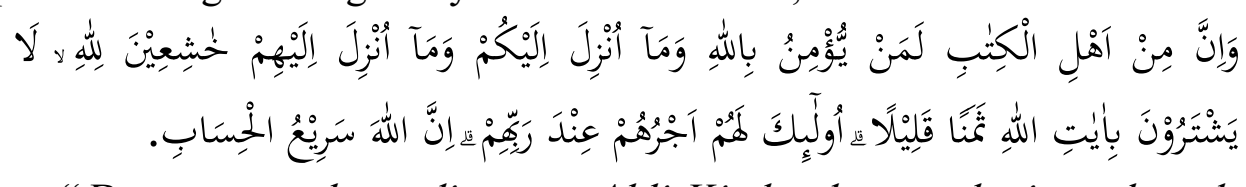

"Dan sesungguhnya di antara Ahli Kitab ada yang beriman kepada Allah, dan kepada apa yang diturunkan kepada kamu, dan yang diturunkan kepada mereka, karena mereka berendah hati kepada Allah, dan mereka tidak memperjualbelikan ayat-ayat Allah dengan harga murah. Mereka memperoleh pahala di sisi Tuhannya. Sungguh, Allah sangat cepat perhitungan-Nya." (QS. Ali 'Imran [3]: 199)

Husein Muhammad sepakat bahwa teman atau saudara kita tidak hanya sesama umat Muslim saja, tetapi juga dari kalangan non Muslim. Bahkan makna kata 'keluarga' dari pernyataan "Yang paling dicintai Allah ialah yang paling banyak memberi manfaat kepada keluarganya" itu bermakna orang lain yang tidak sedarah, namun orang yang seagama, sesama

${ }^{22}$ Husein Muhammad, Toleransi Islam, 1-2. 
umat beragama, orang yang se-tanah air juga termasuk keluarga. ${ }^{23}$ Umat beragama, baik Muslim itu sendiri maupun non Muslim tingkat keimanannya beragam. Ada yang benar-benar meyakini keesaan Tuhan dan menjalankan segala tuntunan yang telah digariskan oleh-Nya, ada yang meyakini keesaan Tuhan namun tidak menjalankan syariat yang sudah ditetapakan; bahkan ada pula yang tidak meyakini keesaan Tuhan dan tidak menjalankan syariat-Nya. Bahkan umat agama lain yang memiliki pengetahuan akan agamanya -yang dalam ayat tersebut disebut sebagai Ahl $a l-K i t a \bar{b}$ - ada yang meyakini kebenaran ajaran Islam dan apa yang diwahyukan di dalam Alquran. Sebut saja seperti kelompok orientalis yang dengan sepenuh hati mempelajari ajaran dan ilmu keislaman, tanpa meninggalkan keyakinan yang telah lama dianutnya. Hal itu mengindikasikan bahwa kelompok Ahl al-Kitāb yang disampaikan dalam ayat ini tidak seluruhnya kafir. Kafir menurut Husein Muhammad merupakan orang yang menentang dan menolak kebenaran dan keadilan, padahal dia mengerti kalau itu adalah adil dan benar. ${ }^{24}$ Sehingga, kafir dapat disandang oleh siapa saja termasuk umat Islam sendiri.

Husein Muhammad mengemukakan pandangan bahwa sebenarnya Islam hanya merumuskan konsep dan prinsip dasar dalam beragama dan bermuamalah. Sehingga, dalam menentukan konsep negara, Islam memberikan prinsip dasar berupa terciptanya kemaslahatan. Ia menyebutkan bahwa terdapat lima prinsip untuk menuju kemaslahatan, yaitu Hifż al-Din (perlindungan terhadap keyakinan seseorang dalam menganut agamanya), Hifz al-Nafs (perlindungan terhadap jiwa yang berkaitan dengan hak hidup, hak untuk merasa aman dan sebagainya), Hifz al-'Aql (kebebasan berpikir, berekspresi, mengutarakan pendapat, berorganisasi dan berkarya secara luas), Hifź al-Nașl (perlindungan terhadap kesehatan reproduksi dan segala hak yang menyangkut di dalamnya) dan Hifž al-Māl (perlindungan atas harta kepemilikan, termasuk kebebasan untuk berkarya). ${ }^{25}$

Lima prinsip yang disebut sebagai al-Kulliyāt al-Khamsah tersebut diperkuat oleh pernyataan Kiai Ali Yafie yang menyatakan bahwa Hifź alNafs (yang didahulukan) dan Hifz al-Din ditempatkan di urutan terakhir. Alasannya ialah, semua manusia apapun identitasnya harus hidup, berhak hidup. Kemudian agama menempati urutan terakhir sebagai pelindung melingkupi semua prinsip yang ada untuk kemaslahatan umat manusia. Oleh karenanya dapat disimpulkan bahwa setiap umat manusia, setiap makhluk Tuhan memiliki hak untuk dilindungi, diterima keberadaannya dan

23 Wawancara dengan Husein Muhammad pada tanggal 11 Juni 2020 di kediamannya.

${ }^{24}$ Wawancara dengan Husein Muhammad di kediamannya pada Kamis, 11 Juni 2020.

${ }^{25}$ Nurcholis Madjid, "Percakapan dengan Husein Muhammad," (22 Mei 2007), 910. 
dimuliakan tanpa memandang perbedaan-perbedaan yang melekat pada masing-masing individu. ${ }^{26}$

\section{Konsep Kebebasan Beragama}

Di dalam Alquran telah jelas disebutkan bahwa Allah tidak menghendaki adanya pemaksaan atas manusia untuk menganut agama apapun. Allah berfirman,

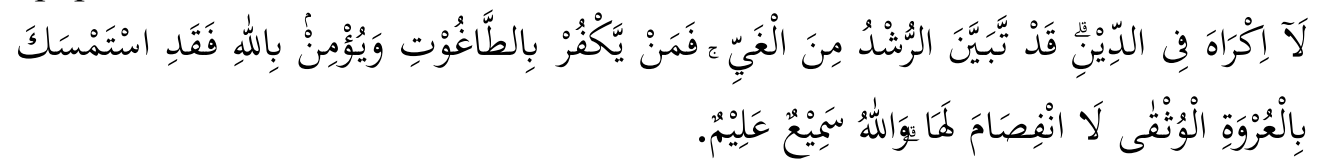

"Tidak ada paksaan dalam (menganut) agama (Islam), sesungguhnya telah jelas (perbedaan) antara jalan yang benar dengan jalan yang sesat. Barang siapa ingkar kepada Tagut dan beriman kepada Allah, maka sungguh, dia telah berpegang (teguh) pada tali yang sangat kuat yang tidak akan putus. Allah Maha Mendengar, Maha Mengetahui." (QS. Al-Baqarah [2]: 256)

Ayat ini hendak menegaskan tidak diperkenankan adanya pemaksaan atas seseorang untuk memeluk agama dan kepercayaan yang diyakininya. Ketika seseorang sudah menetapkan hatinya untuk menganut suatu agama (sekalipun terlepas dari agama yang dianut orang tuanya), maka kita tidak boleh memaksanya untuk menganut agama yang kita anut. Manusia memiliki akal dan hendaknya digunakan untuk memilah mana perkara yang baik dan mana yang buruk. ${ }^{27}$ Menjalankan kaidah keagamaan hendaknya didasarkan atas kesadaran diri penuh tanpa ada intervensi dari siapapun. Oleh karenanya ketika terdapat pemaksaan terhadap apa yang diyakini seseorang, maka yang terjadi ialah hilangnya rasa peduli dan tanggung jawab at as apa yang seharusnya menjadi kesadaran dalam dirinya.

Oleh karenanya hidup berdampingan tanpa mengusik agama orang lain merupakan suatu bentuk kebaikan yang nyata, karena masing-masing punya syariat dan keyakinan masing-masing tanpa harus dicampur-adukkan apalagi disamakan. Allah berfirman,

${ }^{26}$ Husein Muhammad, Dialog dengan Kiai Ali Yafie: Hak Asasi Manusia, Pancasila, Negara Bangsa, Peran Akal, Konservatisme Peradaban Teks, Tafsir dan Upaya Mendialogkan Teks dan Realitas (Yogyakarta: IRCiSoD, 2020), 20-23.

27 Husein Muhammad dan Faqihuddin Abdul Kodir, "Akar Keislaman untuk Mengelola Perbedaan Agama dan Keyakinan”, dalam Menggagas Fiqh Ikhtilaf Potret dan Prakarsa Cirebon, ed. Marzuki Wahid (Cirebon: Fahmina Institute, 2017), 205. 


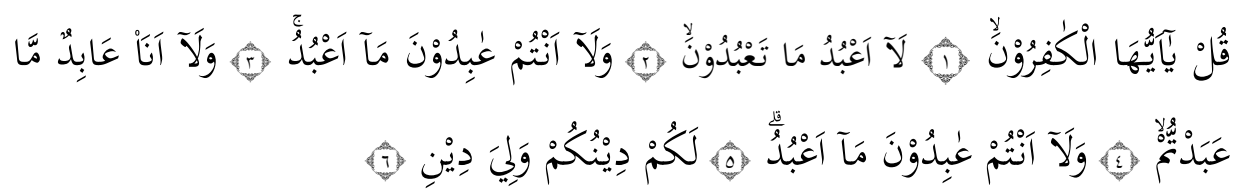

“(1) Katakanlah (Muhammad), "Wahai orang-orang kafir! (2) aku tidak akan menyembah apa yang kamu sembah, (3) dan kamu bukan penyembah apa yang aku sembah, (4) dan aku tidak pernah menjadi penyembah apa yang kamu sembah, (5) dan kamu tidak pernah (pula) menjadi penyembah apa yang aku sembah. (6) Untukmu agamamu, dan untukku agamaku." (QS. Al-Kāfirun [109]: 1-6)

Dari ayat satu hingga ayat empat memperlihatkan bahwa antara ajaran agama yang satu dengan agama yang lain tidak dapat disatukan bahkan disamakan. Masing-masing memiliki aturan dan ketentuan tersendiri yang bisa jadi tidak cocok ketika diterapkan dalam agama lain. Dengan adanya kesadaran tersebut, muncullah sikap toleransi untuk menerima dan mempersilahkan orang lain menganut agama yang diyakininya dengan baik sesuai dengan redaksi ayat keenam. Hal tersebut merupakan suatu bentuk penghormatan atas praktik keagamaan orang lain, dengan menghargainya dan tidak mencampur-adukkannya dengan ajaran umat agama lain. ${ }^{28}$ Meskipun begitu, setiap umat beragama tetap dapat hidup berdampingan dengan saling berbuat baik dan menghargai perbedaan yang terdapat dalam masing-masing umat.

\section{SIMPULAN}

Pluralisme agama menurut Husein Muhammad merupakan suatu keniscayaan yang Tuhan berikan untuk bisa dipahami dan diamalkan oleh umat manusia. Pluralisme agama menghendaki bagaimana suatu paham akan adanya pluralitas terutama dalam aspek agama mendapat justifikasi secara teologis. Kunci utama pluralisme agama ialah pesan-pesan di dalam Alquran yang berperan sebagai pembawa petunjuk untuk menjunjung tinggi nilainilai kemanusiaan. Kemudian, setiap umat beragama memiliki ciri khasnya masing-masing yang tidak dapat dicampur-adukkan satu sama lain. Sehingga pluralisme agama bukan hendak menyamakan agama, melainkan menjembatani umat beragama untuk berdialog dan membangun masyarakat yang saling memperjuangkan hak-hak kemanusiaan diri dan orang lain.

\section{DAFTAR PUSTAKA}

Esack, Farid. Alquran, Liberalisme, Pluralisme Membebaskan yang Tertindas. Diterjemahkan oleh Watung A. Budiman. Bandung: Mizan. 2000.

${ }^{28}$ Husein Muhammad, Toleransi Islam, 6. 
Muhammad, Husein dan Faqihuddin Abdul Kodir. "Akar Keislaman untuk Mengelola Perbedaan Agama dan Keyakinan." dalam Menggagas Fiqh Ikhtilaf Potret dan Prakarsa Cirebon. ed. Marzuki Wahid. Cirebon: Fahmina Institute. 2017).

Muhammad, Husein. “Kebebasan Beragama dan Kekerasan Atas Nama Agama". dalam Menggagas Fiqh Ikhtilaf Potret dan Prakarsa Cirebon. ed. Marzuki Wahid. Cirebon: Fahmina Institute. 2017. . Dialog Dengan Kiai Ali Yafie: Hak Asasi Manusia, Pancasila, Negara Bangsa, Peran Akal, Konservatisme Peradaban Teks, Tafsir dan Upaya Mendialogkan Teks dan Realitas. Yogyakarta: IRCiSoD, 2020.

Yogyakarta: IRCiSoD. 2019.

Islam Tradisional yang Terus Bergerak.

Mengaji Pluralisme kepada Mahaguru Pencerahan. Bandung: Mizan. 2011. . Menyusuri Jalan Cahaya. Yogyakarta: Bunyan. 2013. Press. 2019. . Samudra Kezuhudan Gus Dur. Yogyakarta: Diva . Toleransi Islam. Cirebon: Fahmina Institute. 2015.

Muhtarom. "Mempertimbangkan Hermeneutika Farid Esack untuk Membangun Kerukunan Hidup Umat Beragama." at-Taqaddum Vol. 7 No. 2 (November 2015): 191-209.

Nurcholis Madjid. "Percakapan dengan Husein Muhammad." http://nurcholismadjid.org/assets/pdf/pengaruh/Percakapan-denganHusein-Muhammad.pdf.

Nuruzzaman, M. Kiai Husein Membela Perempuan. Yogyakarta: Pustaka Pesantren. 2005.

Sumbulah, Umi \& Nurjanah. Pluralisme Agama, Makna dan Lokalitas Pola Kerukunan Antarumat Beragama. Malang: UIN-Maliki Press. 2013.

Susanti. "Husein Muhammad Antara Feminis Islam dan Feminis Liberal." Teosofi: Jurnal Tasawuf dan Pemikiran Islam Vol. 4 No.1 (Juni 2014): 197-219.

Wahyudi, Dede. "Pengakuan Akademik atas Pemikiran Kiai Husein Muhammad" NUOnline. 27 Maret 2019. Diakses melalui http://nu.or.id/post/read/104121/doktor-honoris-causabuah-ataspemikiran-kiai-husein. 